\title{
The Global in Canada
}

\author{
Srdjan Vucetic \\ Graduate School of Public and International Affairs (GSPIA), University of Ottawa \\ 7,000 words, 1 cartoon \\ "Generations: The Sources and Evolution of Canadian Foreign Policy" \\ September 28-29 2016, Hart House, University of Toronto
}

Canadian Foreign Policy (CFP) is a partially autonomous, multi- and interdisciplinary field of study that produces convincing knowledge about, and critiques of, Canada's foreign policy or more broadly Canada's position in global affairs. As such, CFP is also an exclusive club that commands a degree of cultural power in society. What follows is a self-narrative account of how I ended up in this club and therefore in this themed issue. My goal is to address two binaries put forward by the editors. One is "inside/outside"-a prompt for reflection about the intellectual, social, cultural and other dynamics that shape our ideas, scholarly and otherwise, about Canada's foreign policy. One is "pessimism/optimism" - a prompt for reflection on the future of the field. I address the first binary in sections entitled "Toronto," "York," "Ohio State," and "Ottawa", four toponyms that categorize my academic progression thus far. I address the second binary in the last section, "Game Over?" 
Following Pierre Bourdieu, I take it as a given that academics, like all social actors, cannot help but strategically position themselves relative to other actors, both individual and institutional. While this occurs daily in every aspect of social life, it is especially pervasive within one's primary academic field of fields. ${ }^{1}$ I thus cannot narrate my position within CFP and the nearby field of International Relations (IR) without simultaneously thinking about strategy and power relations. Example: does being on the outside ${ }^{2}$ give one double or triple consciousness and thus special tools for uncovering aspects of this field that may have been overlooked? A natural temptation is to answer in the affirmative because material and symbolic power usually accrues to those who can legitimately claim such specialness.

Bourdieu's advice is to resist this self-serving tendency. For one, the fact that most things in life indeed appear inevitable or logical only in hindsight is often lost on biographers and perhaps especially autobiographers. Or, as Bourdieu put it himself: "any biography project is predicated on the human desire to show coherence where objectively none exist."’3

\footnotetext{
${ }^{1}$ Pierre Bourdieu, "The Specificity of the Scientific Field and the Social Conditions of the Progress of Reason," Transl. by Richard Nice, Social Science Information 14: 6 (1975): 19-47. A more complete field analysis would mobilize other parts of the Bourdieusian conceptual apparatus, a common intellectual source for my generation of CFP/IR scholars, while also considering everything from research and teaching practices to policy and media work to voting patterns to food consumption. For further discussions, see Vincent Pouliot and Frédéric Mérand, "Bourdieu's concepts," in Rebecca Adler-Nissen, Bourdieu in International Relations (London: Routledge, 2013) and Deborah Reed-Danahay, Locating Bourdieu (Bloomington: Indiana University Press, 2005).

${ }^{2}$ On the multitude of outsider-insider dynamics in the context of academia in general and CFP in particular, see, inter alia, Reed-Danahay, Locating Bourdieu, Ch.3; Wayne Cox and Kim Nossal, "The 'Crimson World': The Anglo Core, the Post-Imperial Non-Core, and the Hegemony of American IR," in Arlene B. Tickner and Ole Wrver, eds. International Relations Scholarship Around the World (New York: Routledge, 2009), pp. 287-305; Heather Smith, "The Disciplining Nature of Canadian Foreign Policy," in J. Marshall Beier and Lana Wylie, eds., Canadian Foreign Policy in Critical Perspective (Don Mills, ON: Oxford University Press, 2010), 1-14; Jérémie Cornut and Stéphane Roussel, "Canadian Foreign Policy: A Linguistically Divided Field," Canadian Journal of Political Science 44: 3 (2011): 685-709; David Grondin, "Languages as institutions of power/knowledge in Canadian critical security studies," Critical Studies on Security 2: 1 (2014), 39-58 and Stephen M. Saideman, "Canadian Scholarship on International Relations: Unified, Divided or Diverse?" International Journal 71 (2016): 193-213.

${ }^{3}$ Pierre Bourdieu, "The Biographical Illusion (1986)," Transl. by Yves Winkin and Wendy Leeds-Hurwitz, in Paul Du Gay, Jessica Evans, and Peter Redman, eds., Identity: A Reader (London: Sage, 2004), 297-303, at p. 298.
} 
The other major problem concerns reflexivity. If it is true that some subject positions are durable because they are taken for granted, unselfconscious and inaccessible though language, then there are inherent limitations to any autobiographical introspection. After all, what is there to suggest that academics possess greater reflexive capabilities and so greater chance of snapping out their habituated dispositions and doxic assumptions than nonacademics? ${ }^{4}$

Bourdieu's warnings are well-taken. But while there are good reasons to think of academic autobiography as the worst kind of fiction, here I wish to stress Bourdieu's concession that all biographies provide some insight into "the operation of dominant ideologies and discourses." This perspective, I hasten to add, is consistent with Bourdieu's late-career call for more "social self-analysis" as well as with some of his finest work-recall masterful his use of autobiographic narratives in Homo Academicus and The State of Nobility, for example. ${ }^{6}$ Assuming that they are read not for individual and collective memories but rather for imaginaries, I would thus posit that self-narratives are a usable method for producing sociologies of knowledge, this generational analysis of CFP included. ${ }^{7}$

\footnotetext{
${ }^{4}$ Notwithstanding the fact that the former have plenty of time to think and are also trained to do so critically engaging ideas both grand and bland, the world's wicked and super-wicked problems as well as-it should be said - the conditions of labouring under permanent scrutiny of their peers (not all of whom are frolleagues). On academic conformity, see Craig Calhoun, "Pierre Bourdieu in Context" (2002), Retrieved on 11 August 2015 from www.nyu.edu/classes/bkg/objects/calhoun.doc, pp. 18-9; and Reed-Danahay, Locating Bourdieu, p.1.

${ }^{5}$ Ibid.

${ }^{6}$ For discussions, see Calhoun, "Bourdieu," pp. 6-7, 33, 44, and Reed-Danahay, Locating Bourdieu, Ch.3. Also, Bourdieu would probably agree that some academics are good at self-reflexivity. Most standpoint theorists spring to mind.

${ }^{7}$ On the conceptual relationship between the concept of generations on the one hand and ideology, discourse and imaginary on the other look no further than these recent contribution to IR theory: Brent J. Steele and Jonathan Acuff, eds. Theory and Application of the 'Generation' in International Relations and Politics (London, Palgrave, 2012) and Tim Luecke, "Generations in World Politics: Cycles in U.S. Foreign Policy Change, the Construction of the 'West,' and International Systems Change, 1900-2008", PhD dissertation, Political Science, Ohio State, 2013.
} 


\section{Toronto}

A good starting is 1994, the year in which I crossed the Atlantic for the first time and settled in Toronto. A glossy legal size paper broken into 47 boxes and lines the then Ministry of Employment and Immigration named IMM 1000 Record of Landing, a.k.a. Fiche Relative Au Droit D’Établissment—my first piece of Canadian ID—describes me thus:

Boxes 2-3, Surname \& Name, minus the "special characters" đ, č and ć; Box 7, Country of Birth: "Bosnia, 048";

Box 10, Citizen of: "Stateless, 979”;

Box 15, Name, Address and Relationship Willing to Assist: "Metro Toronto Imm Sett Services, Ontario, 3812";

Box 20, Special Prog.: "REF";

Box 41, Carrier/Flight No.: “AC873,” etc.

A Bourdieusian might say that I am being strategic here, for this story—dispossession, exile, resettlement-carries symbolic capital value among a large segment of the Canadian elite and possibly a degree of cultural production value within CFP and cognate fields. However, this does not diminish the fact that my experience of war, more than any other personal experience, is what has compelled me to systematically think world politics - that is, to keep reading, writing and talking about political violence, ethno-racism, transnational movements, state sovereignty and all that.

My first months in Toronto were at once exhilarating and depressing. The first, obviously, was a function of resuming "normal life" under the conditions of peace, order, 
and good government, to use Canada's favourite pleonasm. The second had to do with what my colleague Aida Hozić calls the "banality of survival"— not the disoriented "why I am here?" but the guilt-ridden "why am $I$ here?"8 I can explain this duality by reconstructing my memory of "World Issues," a course that I took upon enrolling in my shiny new Toronto high school. Mr. Sanders, an Englishman (his word) who taught it, relished taking on taboo subjects, especially those revolving around Canada's ethical foreign policy. (The idea that Canadians are genteel peacekeepers was his favourite). He all liked provoking students, especially the quiet and reserved. 'Srdjan, wasn't the Cold War better for you and your family?" At first, this was unnerving. Is this guy seriously asking me to intellectualize on my trauma? Now? In front of all these people??

Two of my "real" peers_-meaning students whose age and immigration experiences were similar to mine-intervened by challenging me to think of Mr. Sanders' class as a cross between English speaking practice opportunity and cognitive behavioural therapy. I responded by preparing a "current events" presentation. The topic: the General Framework Agreement for Peace in Bosnia and Herzegovina, better known as the Dayton Accords. "The new inter-entity line goes right through my flat: the living room is in what now will be called the Federation of Bosnia and Herzegovina and the kitchen is in the so-called Republika Srpska," I explained to a pleasantly aghast audience. "This absurdity was in fact predicted in a popular prewar TV Sarajevo show called The Surrealist Hit Parade..."10

\footnotetext{
8 Aida A. Hozic, "The Banality of Survival," in Narrative Global Politics, Naeem Inayatullah and Elizabeth Dauphinee, eds. London: Routledge, 2016, 64-72.

9 'To me, Forest Hill Collegiate Institute looked a lot like a set for Beverly Hills, 90210, CBS TV series whose global popularity covered prewar Sarajevo. Today perhaps better known as "Drake's high-school", Forest Hill is under government review due to declining enrollment.

${ }^{10}$ In 2001, Irish judge Diarmuid Sharidan, appointed by Bosnia's then Austrian proconsul Wolfgang Petritsch, awarded the entire street to the Bosniak-Croat federation (Office of the High Representative, Arbitration Award for Dobrinja I and IV, 17 April 2001, on file with the author). Property rights were never fully sorted
} 
Little I said that day made sense to my classmates. As for me, the more I spoke, the more I felt unslumped. The peculiar peer effects operating in this class eventually positively impacted my written expression too. Entitled "No Peace in the Middle East," my term paper analyzed a dozen Israeli and Palestinian jokes that I thought meaningful in examining patterns of amity and enmity. A minus meaningful, it turned out. "You can think, but you need to learn how to write," Mr. Sanders said with a wry smile. Foreshadowing my future, he then proceeded to offer me an $R \& R$.

Nineteen years old and still fresh off the jumbo jet I was of course confused about "what next?" Confused but not lost, however, for my habitus pointed to higher education. It was Mr. Sanders who told me about the University of Toronto's undergraduate IR program. Not everyone thinks highly of a subject that borrows so liberally from nearby fields of inquiry, notably economics, political science and history but also anthropology, geography, law, philosophy and sociology. But for me IR's catch-as-catch-can character was precisely the attraction. The New Keynesian Phillips curve in the morning, Zhou Enlai versus the Gang of Four for lunch, theories of nationalism in the afternoon; every day I was surrounded by novel ideas that I had never heard before-what's not to like? ${ }^{11}$

Another attraction was that which a continental European never takes for granted: the amount of individual attention "actual professors" were willing to give to students. The person who convinced me that I needed more IR in my life was Professor Arthur Rubinoff. "Good work," he told me. "The last A plus I gave in this class was to Kim Richard Nossal in 1973." Spanning Kautilya and Kenneth Waltz, his POL416 "Theories of International

out, however. Many residents of my former neighbourhood still pay hydro bills to one entity and water and sewage to the other. Political anthropologist Stef Jansen has been chronicling this history for some years now, most recently in his book Yearnings in the Meantime: Normal lives' and the State in a Sarajevo Apartment Complex (New York and Oxford: Berghan Book, 2015).

${ }^{11}$ Years later one seasoned Canadian journalist intimated to me that the program was intended to be Canada's answer to Oxford's PPE, the incubator of Britain's ruling class, and that "it went in a different direction." 
Relations" was intimidating even for graduate students, which is why a few of us decided to meet and discuss the readings an hour before each session - a seminar before the seminar. But Rubinoff was onto us. Applauding our zeal, he sat down to join us on the very first day — and continued to swing by every week henceforth. For the last session he had all of us for dinner at his home. Naturally, he remained manifestly no-nonsense throughout. Skim the readings or skip the page number when citing and he would make you pay, every time.

\section{York}

That IR seminar inspired me to apply to York's political science MA program. "Their department is divided between number crunchers and Marxists," one of my grad school-bound know-it-all peers told me, "but they work as a community." He was right about the Marxists and about the community, especially during that academic year. What better way to build the latter than with a wintertime strike led by the former? I met no number crunchers, however. Instead I met an army of "crits" and "posties," most of whom were in IR.

Accordingly, there was little overlap between Sandra Whitworth's syllabus and Rubinoff's. Having browsed the latest issues of a few American and British IR journals displayed on the fourth floor shelves of Robarts Library, I came to York convinced that "constructivism" was now a thing. Ted Hopf's review articles in International Security and American Political Science Review told me so explicitly. But at York that constructivism went to the shooting gallery, with Alexander Wendt's Social Theory of International Politics playing the role of the leading duck. That constructivism also could not quite prepare me for the departmental seminar series: Shannon Bell's "Fast Feminism"; David Campbell's "Imaging 
the Concentration Camps"; Cynthia Weber's "Faking it with Graduate Students"...This was all new to me.

Undeterred, I proceeded with my main plan: to shine bright new light on the postCold War shifts in the international politics of the Balkan region by following the theoretical primer laid out in Emanuel Adler and Michael Barnett's Security Communities volume. Aside for no shortage of rookie enthusiasm for that constructivism, I was in possession of fresh data that I had collected in 1999 in Sarajevo, the city I then still called home. (An opportunity to work as an interpreter during the region's first post-Kosovo War summit became an opportunity to collect hockey bag-sized cache of documents I pompously called field notes). Two Davids, the "mainstream" Dewitt and the "postie" Mutimer, agreed to supervise my project with considerable interest. Dewitt was known to be open to virtually any theoretical approach to security—so long as you could say something intelligent about how your research might inform policy discourse in a meaningful fashion. As for Mutimer, also known as the Mutilator among the upper-years, his role was to keep my feet to the fire of Critical Security Studies, then a budding new field. And so he did, until the very end. "You are still not thinking like a constructivist," was his verdict at the oral defence. A-minus with a warm invitation to $R \& R$.

Why constructivism? Lived experience, for one. Already during my Sarajevo days, as Titoist Yugoslavia was collapsing all around me, I became enthralled with "propaganda" and more generally the ability of linguistic practices to structure reality and knowledge- the intrinsic connection between words and action, as constructivists like to put it. Then, at Canadian universities, I learned bigger words, like ethnomethodology and hermeneutics. The word identity was also pretty big — all those theories about modern notions of the self and 
other, about the politics of belonging and co-belonging. ${ }^{12} \mathrm{My}$ first CFP publication was a consideration of Canada's Iraq War stance from the perspective of Canadian national identity. It was a mix of non-traditional methods and rather traditional CPF precepts such the assumption that the formal foreign policy action of the Canadian government is an expression of the political will of "Canada", a priori treated as a useful category of analysis. ${ }^{13}$

At York I also continued to study modern Germany, building on my German language and literature undergrad minor. My graduate diploma work with the Canadian Center for German and European Studies at York Lanes-much like its equivalent in Refugee and Migration Studies—was meant to be a side show, an opportunity to read more stuff. Instead, it broadened my conception of politics and the political as much as the MA program itself. Better yet, the diploma catapulted me to the Free University of Berlin on a scholarship for a year. Thomas Risse, one of the engines of that constructivism in Europe, had just moved there to teach and was happy to have a Yorkie in his seminars.

From Berlin I applied to five U.S. PhD political science programs that I classified as constructivist IR-friendly, and got into two. I chose the one that had Hopf. A Bourdieusian in a field that was slowly beginning to think with Bourdieu, Hopf specialized in identity and had an interesting book on Soviet and Russian foreign policy coming out later that year. ${ }^{14}$ Plus he enthusiastically responded to an introductory email I sent him.

\footnotetext{
${ }^{12}$ For a philosophically intense engagement with "identity" that happens to accent the siege of Sarajevo, see Jean-Luc Nancy, “Eulogy for the Mêlée,” In Nancy, Being Singular Plural. Translated by Robert D. Richardson and Anne O’Byrne (Stanford: Stanford University Press, 2000), 145-158. IR's idea of identity studies interests me still: Srdjan Vucetic, "Identity and Foreign Policy," in Cameron Thies, ed. Oxford Research Encyclopedia of Politics (2017).

13 Srdjan Vucetic, "Why did Canada sit out the Iraq War? One Constructivist Analysis," Canadian Foreign Policy 13: 1 (2006): 133-153. At this time, constructivist conceptual prosthetics had already been old news in CFP. See in the same journal for example: Peter Howard and Reina Neufeldt, "Canada's Constructivist Foreign Policy: Building Norms for Peace,” Canadian Foreign Policy 8: 1 (2000): 11-38.

${ }^{14}$ Ted Hopf. Social Construction of International Politics: Identities and Foreign Policies, Moscow, 1955 and 1999. Ithaca, NY: Cornell University Press.
} 


\section{Ohio State}

To be allowed to take comprehensive examinations in my major and minor fields, I

had to take 27 rather intensively taught courses - and this was after the department granted the maximum number of equivalencies for courses I completed at York and Berlin, and on top of the coursework and workshops done outside the program itself such as, for example, the training institute on qualitative research methods I attended at Arizona State. "Methods training" was something of a Maoist slogan. All students, even political theory majors, had to take courses in research design, probability theory and intermediate regression analysis. The “advanced quant" sequence was merely "strongly recommended."

This was not necessarily madness. Within any field of inquiry that prides itself on its "pluralism"- not to mention some form of multi- and inter-disciplinarity, as in CFP and IR_few scholars would ever argue in favour of some theoretical or methodological monoculture, much less against a common textbook dictum is that research should be question-driven as opposed to theory-, method-, or data-driven. What is less conventional is the willingness to walk the walk-that is, to actually conduct research across multiple approaches, traditions, and communities. Ohio State challenged me to try just that. This is neither easy not very strategic. To dabble in, and fiddle with, historical institutionalism, actor-network theory, performances, neo-Gramscianism etcetera, with all the different attendant methodologies and aesthetics in tow, requires one to dance around the "master of none" trap, to accept contradictions and take professional risks. (Imagine confiding to constructivist IR frolleagues that you "provisionally" accepted narrow materialist ontologies and are about to test hypotheses in an ever-expanding number of observations. Nine out of 
ten times they will tell you to "keep an open mind but not so open that your brains fall out".) Whatever the overall value added/subtracted of such transgressions, I am convinced they make me a better consumer of social scientific knowledge and a much better teacher.

For my dissertation I decided to write on the rise of the "Anglosphere" and its impact on the modern international system. The topic was unusual, but it received full support of the constructivist IR dream team that became my committee: the aforementioned Hopf and Wendt, plus Jennifer Mitzen, the founder of ontological security studies. The project began with an observation that the talk of Anglosphere unity, then a rarified conservative pastime, was in fact quite old, going back to the nineteenth century. The Anglosphere also appeared reliably reflected in, and reinforced by, countless discourses, institutions and practices. Everywhere I looked select English-speaking countries cooperated and collaborated with each other far more than textbook IR theories would allow. The claim made in my dissertation, which now masquerades as a $\$ 20$ book, was that Anglosphere cooperation and collaboration patterns are racial in origins; that is, to understand post-1945 Pax Americana, and a special role played by Britain and its dominions in it, Canada included, one must first understand the history and legacies of Anglo-Saxon supremacism. ${ }^{15}$

Whence interest in race? In Sarajevo, where I was born and raised, it was commonplace to define oneself in multi- or post-ethnic terms: "Yugoslav," "Bosnian," "cosmopolitan," "Sarajevan," etc. With the fall of the Berlin Wall and the advent of democracy, however, non-national identities became subject to routine denial, modification, and stigmatization. The rest of this story is now Political Violence 101 material. And although there are good reasons why the Yugoslav wars are never described as "racialized"

\footnotetext{
${ }^{15}$ Srdjan Vucetic. The Anglosphere: A Genealogy of a Racialized Identity in International Relations. Stanford, CA: Stanford University Press, 2011. By my count only one IR textbook, Oxford's The Globalization of World Politics, has a chapter on race-and only in its upcoming 2017 edition.
} 
in said literature, it might be worth pausing over such a notion. Consider the phrase "recounting of blood corpuscles"-a local sarcasm that aptly captures the political ideology propagated by nationalists in the 1990s. If all humans of Bosnia were really Bosniaks, Croats and Serbs waiting to come out, then it was only logical to cast "children of mixed marriages" as "spares." ${ }^{16}$ Far from being vanquished by NATO bombs, Euro-Atlantic arms-twisting and supranational courts, this brave new ethnopolis has lived on, demonstrating to illiberal forces everywhere how best to package democratic apartheids for use in the twenty first century.

Living, working and studying in the great multicultural majority-minority mosaic that Toronto already was at the turn of the millennium sensitized me to racialized realities further. Why are some Canadians described by themselves and others as "visible minorities"? What does it mean to be "white on arrival"? How does an institution become "systematically racist"? How do "we" reform the Department of Indian Affairs and Northern Development? And why is "intersectionality" so critical? Associated with the so-called campus left (to use but one among many pejorative monikers), such questions are often incomprehensible to most people. But they are all-important. My dissertation research convinced me of it. The more I read about the Anglo-American special relationship and the like, the more I apprehended the centrality of racialized violence in modernity, including liberal modernity. Talking to non-IR folks, such as Ohio State's fabulous folklorist Dorothy Noyes, helped me in this convoluted journey, as did my sideways forays in the high-stakes body of ideas known as postcolonial thought. (One does not venture very far into Bourdieu Studies without coming across Bourdieu's critics like Edward Said or Reawyn Connell, for instance.) These travels will continue for I cannot see a good reason to stop thinking about

16 The story is bewilderingly complex even for area specialists. On Yugoslav and Bosnian inter-ethnicity, see especially Fedja Buric, "Becoming Mixed: Mixed Marriages of Bosnia-Herzegovina during the Life and Death of Yugoslavia." PhD Dissertation in History, University of Illinois, Urbana-Champaign, 2012. Dissertations could also be written on other Bosnian racisms, starting with anti-Semitism and antiziganism. 
race as a shifting system of power relations and practices to which everyone has contributed, about the colonial/imperial causes and consequences of international order, and about the relationship of the academic discourse of race with political activity within and beyond academia.

\section{Ottawa}

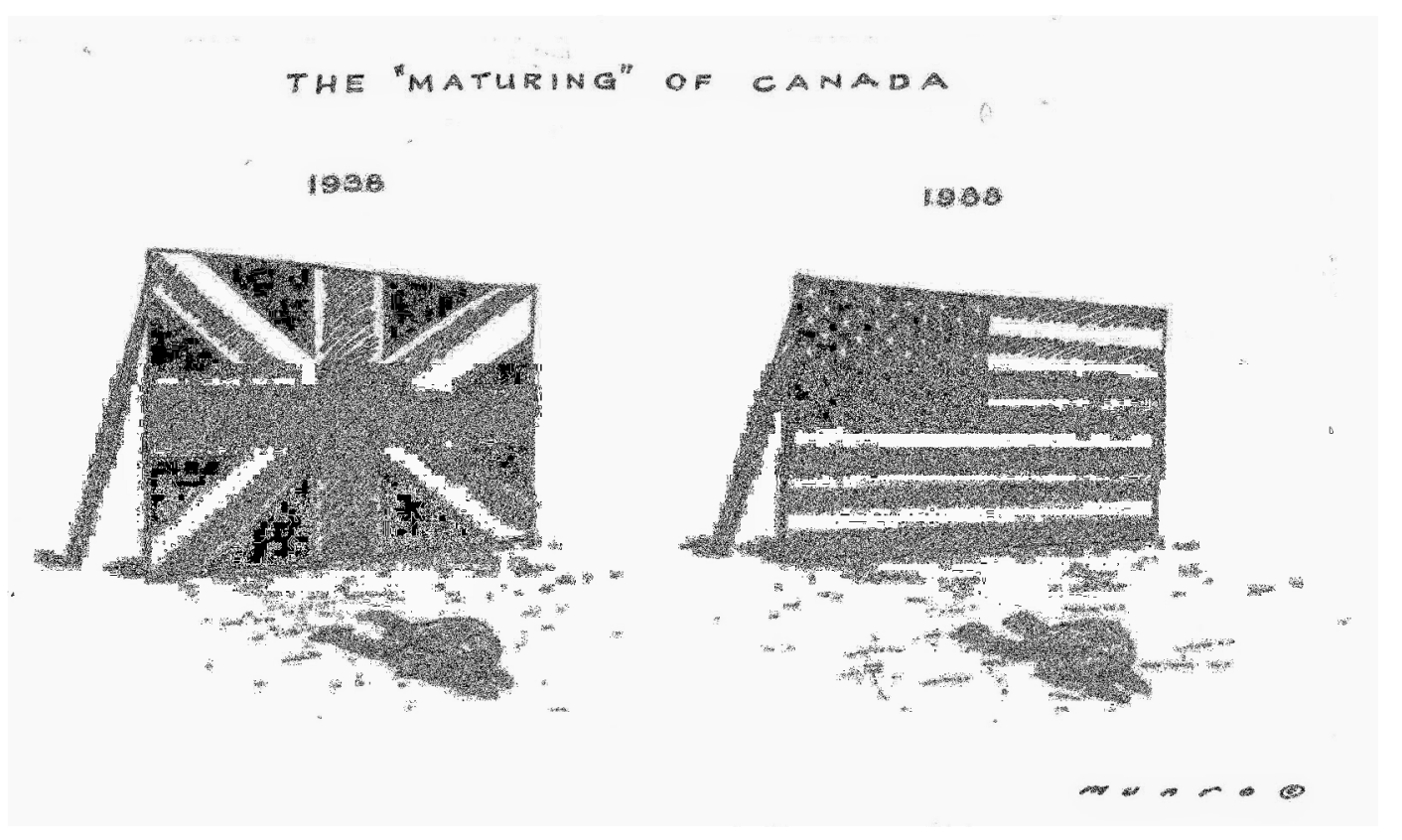

CFP influenced my dissertation project from the beginning. The CFP I read at York greatly increased my exposure to critical perspectives on the modern international. ${ }^{17}$ Same for a sense of the pervasiveness of hierarchies in world politics, colonial and otherwise. Exhibit A: "The "Maturing” of Canada," a NAFTA negotiations-era cartoon by Ken Munro,

\footnotetext{
17 Work on the gendered and racialized nature of peacekeeping, for example: Sherene Razack, "From the 'Clean Snows of Petawawa': The Violence of Canadian Peacekeepers in Somalia," Cultural Anthropology 15:1 (2000), 127-164; and Sandra Whitworth, "Militarized Masculinities and the Politics of Peacekeeping: The Canadian Case." In Claire Turenne Sjolander, Heather A. Smith, and Deborah Stienstra, eds, Feminist Perspectives on Canadian Foreign Policy (Don Mills, ON: Oxford University Press, 2003), 76-89.
} 
as reproduced in my first CFP textbook. ${ }^{18}$ (As one classmate explained to me at the time, this was an apt metaphor for thinking English Canada only.)

I thought of this cartoon on dozens of occasions while doing research. In 1982, when Canada patriated its constitution from the "mother country," the Parliament Hill ceremony literally took place under the watchful eye of U.S. Marines, who saluted the proceedings standing on the U.S. embassy balcony adorned with both the Maple Leaf and the Stars and Stripes. ${ }^{19}$ Many Canadians naturally have traditionally resisted the international hierarchical organization pivoting on the U.S. Shortly after this particular maturing of Canada, the political scientist Niels Ørvik and journalists Peter Newman both penned important treatises urging Ottawa to spend more on defence in order to turn the country, in the latter's memorable words, into "a wholly dependent colony, owing our safety and continued existence to the tender mercies of the Pentagon." 20

Similar arguments can be heard during this year's defence policy review public consultations. How long will Canada's U.S.-furnished security and prosperity last if successive Canadian governments continue to effectively disarm the country, to say nothing of playing coy with ballistic missile defence and NORAD modernization? Following Maureen Appel Molot's assessment of CFP scholarship written in the last days of the Cold War, I bet that one would have no difficulty finding major texts penned by Canadian

\footnotetext{
${ }_{18}$ Norman Hillmer and J. L. Granatstein, Empire to Umpire: Canada and the World to the 1990s (Toronto: Copp Clark Longman, 2007, Second edition), p. 345. I am grateful to Ken Munro for allowing me to reproduce his work here (e-mail correspondence).

${ }^{19}$ For my take on this moment, see Vucetic, "The Search for Liberal Anglo-America: From Racial Supremacy to Multicultural Politics," in Peter Katzenstein, ed. Anglo-America: Civilizational Politics Beyond West and East (London and New York, Routledge, 2012), 120-41.

20"Nils Ørvik, "Canadian Security and 'Defence Against Help,"” International Perspectives (May/June 1983): 3-7. Peter C. Newman. True North. Not Strong and Free: Defending the Peaceable Kingdom in the Nuclear Age (Toronto, McClelland and Stewart, 1983), at p. 173.
} 
intellectuals addressing Canada's subordinate place in the world in virtually any year since Confederation. ${ }^{21} \mathrm{I}$ also bet that most of these texts are primarily about Anglosphere relations, much as depicted in the Munro cartoon above. ${ }^{22}$

The research design driving my dissertation was vintage CFP advice that viewing Canadian foreign policy patterns should always be done in a context broader than their Canadian setting. Example: how do we explain the differential policies of Australia and Canada in Suez and Vietnam? Prime facie, such research questions are reminiscent of midtwentieth century comparative historical sociology or more specifically of John Stuart Mills's methods of comparison. Yet what is truly compelling about Australia-Canada comparisons is their long "shared history", both as "neo-Britains"—white settler societies committed to the ideologies, institutions and practices of the British Empire-and as major supporters of the post-1945 "rules-based international order" centered on Washington. ${ }^{23}$ Exposure to CFP materials, themselves influenced by Commonwealth Studies and therefore by postcolonial theory, compelled me to always look for such shared histories as well as to formulate research questions that went beyond my American IR default settings. ${ }^{24}$

The one site where I did both archival work and interviews was Ottawa, due to the fact that a quarter of my case studies in my dissertation centered on Canadian foreign policy

\footnotetext{
${ }^{21}$ Maureen Appel Molot, "Where Do We, or Should We, or Can We Sit? A Review of Canadian Foreign Policy Literature," International Journal of Canadian Studies 1-2 (1990): 77-96.

22 I remember being struck with joy when I discovered David Haglund's mention of the Anglosphere in Policy Options: some Canadians will find my topic interesting! Haglund, "Canada and the Anglosphere: In, Out, or Indifferent?" Policy Options (February 2005), 72-6.

${ }^{23}$ Andrew F. Cooper, Richard A. Higgott, and Kim Richard Nossal, Relocating Middle Powers: Australia and Canada in a Changing World Order. Vancouver: University of British Columbia Press, 1993; Jill Vickers, The Politics of Race: Canada, Australia and the United States. Ottawa: Golden Dog Press, 2002; and Margaret MacMillan and Francine McKenzie, eds. Parties Long Estranged: Canada and Australia in the Twentieth Century. Vancouver: University of British Columbia Press, 2003.

${ }^{24}$ Example: what might the 1982 patriation of the Canadian constitution and the 1988 Australian bicentennial have in common from the perspective of nation-building, postcolonial hierarchies, and the development majority-minority interactions? Vucetic, "The Search for Liberal Anglo-America."
} 
episodes. This turned out to be one of the more rewarding aspects of my dissertation experience. Not only did my Toronto and York-era studies in CFP and my dissertation come theoretically and empirically together, but I also got a chance to talk to real people about a real foreign policy spectacle_Prime Minister Chrétien’s non to President Bush’s “coalition of the willing." (Cold shoulder to ballistic missile defence, shown by Prime Ministers Martin and Harper was just as interesting.) Canadian research interests supported a rather Canadianized geography of conferencing, grant-writing, publications and related rites of academic passage, which in turn led me to share a major personal and professional investment in the working of CFP as a field.

Between all this history and the fact that in 2009 I landed a tenure track position at the University of Ottawa's Graduate School of Public and International Affairs, a pathdependent connection might be said to exist. Some might go further and argue that people "make our own luck," meaning that agents react with differential talent, privilege, energy, strategy and persistence to happenstance, serendipity and interpersonal relationships dynamics that change the course of lives. But attributing linearity to "success" is a trick that our minds play on us. Academics should know better-and not just with interest in the intersectionality of privilege or the ignoble exploitation of adjuncts, part-timers, causals, contingent faculty, and other "ghosts in the classroom."25 Anyone paying attention to the dysfunction of academia - I think most of my colleagues would now describe it as a cross between a soul-crushing cult and a Ponzi scheme, dependent on ever more people providing non-permanent and severely underpaid labour to universities—will probably forgive me for feeling the banality of survival again.

\footnotetext{
${ }_{25}$ Michael Dubson, ed. Ghosts in the Classroom: Stories of College Adjunct Faculty-and the Price We All Pay (Boston: Camel's Back Books, 2001).
} 


\section{Game Over?}

From the vantage point of a relative insider now, is it game over for CFP? Scholars much more relevant to this field than me have taken stock of themselves and their work before, offering different answers to this question. ${ }^{26}$ Keeping their insights in mind while looking around from my office in uOttawa's sleek new turquoise tower, I will begin by offer a few reasons for optimism, which I will then qualify by putting them in a broader institutional context. Ensuing observations, note, are a little more than guesswork. Systematic data corresponding to the claims I make below are yet to be compiled, combined with rigorous reflection about the use and abuse of measures and indicators.

Recent years have seen a major reorientation of the concept of foreign policy in its American-dominated academic fields and subfields, above all those centered in, or revolving around, political science and history. In IR, for example, a more narrowly defined "FPA" (Foreign Policy Analysis) is now being replaced with broader "FP" (Foreign Policy) and "AFP" (Analysis of Foreign Policy) approaches. ${ }^{27}$ As an early adopter of the latter perspective, CFP stands to benefit from these trends. Look at any number of CFP publications from the last decade and you will see a field that has moved away from the Canadian state policy viz. other states, that "traditional" foreign policy focus, and towards of what can be called "the global in Canada." This latter rubric is much broader and deeper,

\footnotetext{
${ }^{26}$ Compare, for example, Jean-Christophe Boucher, "Yearning for a progressive research program in Canadian foreign policy," International Journal 69: 2 (2014): 213-228 to Paul Gecelovsky and Christopher Kukucha, "Canadian Foreign Policy: A Progressive or Stagnating Field of Study?” Canadian Foreign Policy 14 (2), 2008, 109119.

27 On FP and AFP, see, respectively Walter Carlsnaes, "Foreign Policy," In Walter Carlsnaes, Thomas Risse, and Beth A. Simmons (Eds.), Handbook of International Relations. London: Sage, 2013, 298-325, and Amelie Hadfield and Valerie Hudson, "North American and European Foreign Policy Analysis," In Klaus Brummer \& Valerie M. Hudson (Eds.), Foreign Policy Analysis Beyond North America. Boulder: Co: Lynne Rienner, 2015: 139168.
} 
covering in everything from the relationship between Canadian foreign policy practices to Canadian state-society relations to the role of variegated networks that produce governance within and beyond Canada to various normative issues that criss-cross Canadian, international and global politics.

Take the aforementioned question of hierarchical relations. The notion that Canada has continuously been peripheral to one ideological-economic-military-political system or another since the moment it came into being as a national territorial entity and that these systems were always hierarchically ordered can be easily accommodated within "traditional" theoretical frameworks for studying foreign policy as a political practice conducted by sovereign, more or less independent states. What complicates things is a move beyond stateand military-centric understandings of the hierarchical organization of the world. To write on Canada in the context of "hierarchies in world politics" or "global hierarchies" as opposed to "international hierarchies" is to engage critically with constructivist, critical, feminist, Marxist, poststructuralist, postcolonial and decolonial research. Many key elements are already in place, in terms of understanding core-periphery relations, hegemony, imperialism, and/or post-coloniality. If Canadian universities are serious about responding to the Truth and Reconciliation Commission's "calls to action", then some of these research areas should soon be receiving a new boost.

Compared to some other national FP fields, CFP is also far more multi- and interdisciplinary as well as far more diverse theoretically and methodologically. True, if International Journal and Canadian Foreign Policy Journal are any indicators, CFP still belongs primarily to IR-ists and political scientists, followed by historians and current and former practitioners. But although sociologists, anthropologists, and economists contribute far less or not at all, insights from these social science disciplines certainly permeate articles 
published in these journals. ${ }^{28}$ The multi- and inter-disciplinary cross-referencing and hybridity is also fostered through multiple scholarly associations with CFP (broadly construed) sections and working groups in which the value of plural and pluralist research interest is recognized and validated. I also notice that CFP is leaving its Canadian shell more and more. Comparisons (again broadly construed) to other national and non-national entities are becoming more common in the field, often following latest guidelines taken from comparative and transnational history or social scientific case study theory. This helps CFP scholars develop explanations and understandings informed by intuitions grounded in a diversity of geographical and cultural locations. ${ }^{29}$

Another potential indicator for measuring the health of the field could be the accomplishments and status of CFP scholars within their respective departments and their professional associations. On this front, all is still well. Years of close participant observation of Canadian academics lead me to reject the hypothesis that those who specialize in CFP are more likely to suffer from professional status anxieties than those who do not. Extending on the same point, I observe that the number of universities offering CFP courses has increased, as has the number of students enrolled in those courses. Same goes for the number of graduate degrees awarded, the number and quality of articles and books published, and the number of university and other presses eager to publish on CFP topics. All of these developments are likely to result in more citations overall, another dimension on which the field looks quite healthy.

\footnotetext{
${ }^{28}$ Comparing past and recent surveys, pluralism has increased within CFP, on some dimensions at least. See, in this journal alone: David R. Black and Heather A. Smith, "Still notable: Reassessing theoretical 'exceptions' in Canadian foreign policy literature," International Journal 69: 2 (2014): 133-151; Brian Bow, "Measuring Canadian foreign policy," International Journal 69: 2 (2014): 229-232; and Philippe Lagassé and Justin Massie, "Canadian security policy: New perspectives and debates," International Journal 64: 3 (2009): 601-604.

29 As an added bonus, in today's global and digital age it is relatively easy to bring together scholars from around the world to collaborate on projects of relevance to CFP.
} 
The bad news are the last few observations are at once evidence of the state of the field as well evidence of a growing demand for "measurable" knowledge production, which in turn has to do with the so-called corporitization of academic life. Certainly, the future of CFP depends on the broader institutional trends in Canadian higher education. Today, the conventional wisdom holds that universities have no choice but to offset ever-dwindling government resources with tuition increases_-international student tuition fees are a big prize - combined with private sector investments and the corollary adoption of managerial policies and practices associated with a free market doctrine loosely called neoliberalism. This result is not simply an intensification of institutional competition, but a dramatic shift in the nature of that competition—witness university leaders talk about "new funding streams" or "upward movement in the QS rankings."

Corporatization of universities is likely to intensify. So viewed, many of the previously cited reasons to be cheerful about the future of the field are in fact good reasons to be depressed about it. To begin with, the fact there is now "more of everything" in CFP has everything to do the increase in the pace and volume of quantifiable academic output and an ethos that scholars should be always visibly on-just take a look at our Twitter feed. The problem with this structure is that it grants fewer and fewer opportunities for analytical rumination and critical dialogue, key prerequisites for the production of good scholarly knowledge as well as for the development of good pedagogical methods. Furthermore, we have no reason to conclude that more intramural CFP chatter means that Canadians are now assigning greater value to CFP scholarship. No basis for revelling in CFP's increasing citation counts, either: these belp measure research productivity of specific individuals and institutions, not the health of a field. 
The most alarming effect of these broader institutional shifts is the casualization of academic knowledge production. If we look at universities across the five Anglosphere countries I mentioned earlier-part of the world mostly closely associated with the idea and practice of an academic "market" — we can observe that more than half of the undergraduate courses are now being taught by workers surviving on a variety of precarious contracts, with little or no retirement benefits. ${ }^{30}$ While this process is adversely impacting the fate of all fields, most threatened are fields that university managers identified as "non-target." CFP is almost certainly one of them. Few CFP scholars I know were hired to specifically do CFP and the number of CFP appointments, whether in history or IR, appears to have dwindled to zero in recent years-developments that undermine CFP's generational turnover under discussion in this collection. At the same time, CFP courses are being turned over to graduate students and contract academic staff in greater numbers. My guess is that the ratio of short-term contracts to full-time tenured or tenure-track positions in CFP is probably above-average and increasing relative to comparable fields.

Casualization minimizes chances for creating a CFP field that is demographically more representative of Canada. The ratio of men to women doing CFP for a living may have significantly dropped over the past two or three decades, but the same cannot be said about most other ratios that are now used to capture "diversity" in Canadian universities. Scarequoting this word is apt since it universities so often misuse it for public relations purposes,

\footnotetext{
${ }^{30}$ Sarah Kendzior, “Academia’s indentured servants," Al-Jazeera, April 11, 2013; Ira Basen, "Most university undergrads now taught by poorly paid part-timers," CBC News, September 7, 2014; Oliver Watts, "Smart Casual," $A C W$ Insight, August 31, 2015; Aditya Chakrabortty and Sally Weale, "Universities accused of 'importing Sports Direct model' for lecturers' pay,” The Guardian, November 16, 2016.
} 
while in essence maintaining the status quo; ${ }^{31}$ indeed, how can anyone give a positive spin to the opening of classrooms to Indigenous, non-white and/or non-male instructors who happen to be part-timers? Extending on the same point, leaving CFP in the hands of adjunct professors has a potential to compromise both the quality of knowledge production and academic freedom in the broadest sense. A professor living precariously from one semester to the next will not only struggle to maintain a strong research profile, but she may also decide to write on less controversial topics in the expectation that this would increases her employability in government or think tanks, should the academic path close.

To conclude, it is possible to be guardedly optimistic about the future of CFP, so long as the emphasis remains on the word guardedly.

7,000 words

${ }^{31}$ Frances Henry, Ena Dua, Carl James, Audrey Kobayashi, Peter Li, Howard Ramos, and Malinda Smith, The Equity Myth: Racialization and Indigeneity at Canadian Universities (Vancouver: University of British Columbia Press, 2017). 